\title{
The Power to Change: A Brief Survey of The Wind Power's Technological and Societal Potential, Barriers to Use, and Ways Forward
}

\author{
Helen Kopnina ${ }^{1}$ \\ ${ }^{1}$ The Hague University of Applied Sciences, The Hague, The Netherlands \\ Correspondence: Helen Kopnina, The Hague University of Applied Sciences, Johanna Westerdijkplein 75, 2521 \\ EN Den Haag, The Netherlands.E-mail: h.kopnina@hhs.nl; alenka1973@yahoo.com
}

Received: October 15, 2019 Accepted: November 22, 2019 Online Published: December 2, 2019

\begin{abstract}
With the effects of climate change linked to the use of fossil fuels becoming more noticeable, political establishment and society appear ready for renewable energy. Yet, despite these expectations, fossil fuels still comprise nine-tenths of the global commercial energy supply. In this article, the history, technology, and barriers to acceptance of wind energy will be explored. The central question is why, despite the problems associated with the fossil fuels, more ecologically benign energy is still scarcely used. Having briefly surveyed some literature on the role of political and corporate stakeholders, as well as theories relating to factors responsible for the grassroots' resistance ("not in my backyard" or NIMBYs) to renewable energy, the findings indicate that motivation for opposition to wind power varies. While the grassroots resistance is often fueled by the mistrust of the government, the governments' reason for resisting renewable energy can be explained by their history of a close relationship with the industrial partners. This article develops an argument that understanding of various motivations for resistance at different stakeholder levels, and understanding the role of democracy in decision-making opens up space for better strategies for a successful energy transition.
\end{abstract}

Keywords: climate change; energy transition; NIMBYs; renewable energy; wind power

\section{Introduction}

The wide-spread public protests against air pollution caused by fossil fuels in Western countries have increased since the nineteen seventies (Zavestovsky, 2010; Perera, 2018). Concerns about climate change and increasing greenhouse gas (GHG) emissions that cause the greenhouse effect and consequently climate change have increased (Pinske and Kolk, 2009). With climate change linked to the use of fossil fuels, hope was expressed that political, corporate, and economic institutions, as well as society as a whole, will switch to renewable energy (Climate Economy Report, 2014; Barthelmie and Pryer, 2014).

Several proposals have emerged, propelled by a public and political interest in the development of renewable energy technologies (Barthelmie and Pryer, 2014; Renewable Energy World, 2015). Solar power and wind power are considered to be the most significant potential source of global low-carbon energy supply, without potential dangers of waste, as in the case of nuclear energy (Brown et al, 2014; Washington, 2015). Unlike fossil fuels, wind power does not contribute to GHG emissions, aside from its capture and storage devices (which can be made using renewable energy), and unlike partial renewables like biofuel, it does not involve replacing biodiverse habitats with monoculture plantations (Eggars et al, 2009; Braungart, 2013).

Yet, despite these expectations and technical innovations and increased affordability of renewable energy, and particularly wind power, at present, fossil fuels continued to supply almost nine-tenths of global commercial energy and climate mitigation efforts have been so far a large failure (IPCC, n.d). As of 2017, renewable energy accounted for an estimated $18.1 \%$ of total final energy consumption (REN21). The global emissions continued to rise after the signing of the Paris agreement in 2015 (Leahy, 2019), partially because not all governments have signed the agreement or attempted to meet the targets (Luttikhuis, 2019).

Considering the importance of renewable energy to combat climate change, this article briefly outlines some of the technological, political, and social dimensions associated with wind power and the reason for opposition to it, outlining possible ways forward. The central question addressed here is why, despite the obvious risks and threats associated with the use of fossil fuels, there is still no radical shift to more ecologically benign forms of energy. 


\subsection{The Challenge of Climate Change and Renewable Energy}

While there is a considerable body of research on climate change, renewable energy, wind power, and resistance to wind power from the governments and corporate stakeholders down to local communities, little has been written about understanding and comparing various motivations for resistance from different levels of stakeholder involvement. The problem of different motivations deserves new research due to the need to resolve inconsistencies between the apparent desire to avoid climate change on the one hand and the inability of governments as well as some communities to facilitate this change. The hypothesis that drives this desk research is that understanding and differentiating between different motives for resistance can help policy-makers to make informed decisions concerning appropriate strategies. Linking theories of the role of political and corporate actors in addressing (or failing to address) sustainability challenges, and using theories relating to sociological and psychological factors responsible for grassroots resistance promises to bring new insights into the study of the energy transition. The brief background, technology, and politics involved in the production of and resistance to the use of renewable energy, and particularly wind energy, will be explored in the sections below.

\subsection{Energy Supply: Brief Background}

Between 1950 and 2005, fossil-fuels supplied over eighty percent of all energy production, igniting rapid changes first in the economically developed countries, and then globally (Nehring, 2009). Between 1950 and 2015, fossilfuel production increased from 1.5 billion to over 10 billion metric tons (EPA, 2015), with carbon dioxide emissions constantly rising (Harvey, 2018). This is due to several factors: the increase in global population and its demands for higher living standards associated with a high level of natural resource consumption, relative peace, and economic competition dependent on exploitation of fossil fuels (Washington, 2015; Kopnina and Blewitt, 2018). As fossil fuel energy became omnipresent and increasingly affordable, it acted as a substitute for other energy inputs in transportation, agriculture, and construction (Smil, 1994; Pinske and Kolk, 2009).

The majority of commercial and private vehicles are running on fossil fuels (Smil, 1994), with car ownership increasing every year (Kopnina, 2011; Buehler, 2018). The number of airplane flights has also increased exponentially in the last two decades (Higham, et al 2014). Higham, et al (2014:336) noted that an increase in aviation is "fundamentally incompatible with radical emissions reduction and decarbonization of the global energy system". Coordinated action and strict government regulation of emissions are needed not just in aviation, but in all energy-intensive sectors (Higham, et al 2019).

In agriculture, the application of energy-intensive artificial fertilizers and pesticide production has increased 1,000 percent globally between 1950 and 2015 (Setboonsarng, 2015). Already in the nineteen sixties, it was noted that the adoption of intensive farming supported by fossil fuels has increased the capacity of productive land and so made possible a 'population explosion' (Ehrlich, 1968). Agricultural advances allowed humanity to appropriate almost half of the entire 'productive' landmass, used for cultivating wheat, rice, corn; and other grain (Kindall and Pimentel, 1994; Setboonsarng, 2015). Fossil fuels, in combination with better medical technologies and food production systems, have caused the global population to grow as never before in human history (Setboonsarng, 2015).

Concomitant with these developments, high per-capita energy consumption has been recognized as a necessary condition for high living standards (UN, 1987). Higher consumption also strengthened a positive feedback loop, forcing people to use land more intensively and to adopt technological innovations that make an even more intensive land use possible (Boserup, 1965). Critics showed that the argument itself is flawed. Eating high on the food chain has led to massive clearing to grow soybeans and corn for feedlots, not using land more intensively. Intensive and sustainable farming are contradictions. Thus, it was argued that with almost eight billion people, it would be unrealistic to strive to attain the same level of consumption for generations to come (Engelman, 2013; Washington, 2015), including consumption of energy. Yet, while research and technology associated with the production of renewable energy have been steadily advancing, energy alternatives have failed to displace the fossilfuel regime (Mitchell, 2009).

\subsection{Challenges to Wind Power}

The intermittent (weather-dependent) nature of wind power has presented challenges to the system capacity (Fang et al, 2011).The wind power can be stored either as electricity in batteries, heat in such media as molten salt, or as hydrogen, compressed air, or pumped storage to a higher level, so that power is available on-demand (UCSUSA, n.d.). Improvement in the design of a battery energy storage system (BESS) has been crucial in attenuating the effects of unsteady power input from wind farms (Teleke, et al, 2009). The design of newer batteries determines the capacity of the BESS to ensure constant dispatched power to the connected grid, while the voltage level is kept constant (Zhao, et al, 2015). 
Globally, such large projects have been somewhat less popular than the application of small wind systems that have demonstrated their ability as distributed energy resources (Akorede, 2010). Distributed energy resources refer to a variety of small, modular power-generating technologies that are combined to improve the operation of the electricity delivery system (Ibid). Yet, large scale use of wind energy is gaining in popularity as electricity storage systems improve (UCSUSA, n.d; REN21). A study by the United States Department of Energy in 2008 found that expanding wind power to 20 percent by 2030 is feasible, affordable, would not affect the reliability of the power supply, and would create new jobs (UCSUSA, n.d.). One of the largest sites of high-voltage power lines spanning 3,600 miles was completed in Texas in 2014 at a cost of $\$ 7$ billion, handling up to 18,000 megawatts and serve millions of households from Austin to Huston (Wald, 2014).

The challenge of integrating wind power into established electric power grids is described in the report Technology Roadmap: Wind Energy by the International Energy Agency (IEA, 2013). The Agency's assessment examines several case studies to determine the ability of anyone's national grid to accommodate renewables using storage, interconnection, and demand-side management (IEA, 2013). The report approximates that wind power could generate up to $18 \%$ of the world's electricity by 2050 , compared with $2.6 \%$ today. The Chinese onshore wind power projects have experienced rapid growth in wind power generation, with China projected to overtake OECD as the leading producer of wind power by 2025, with the United States ranking third (Han et al, 2009). IEA's recent report has estimated that the offshore wind capacity is projected to increase 15 -fold due to approximate $\$ 1$ trillion investment by 2040 (IEA, 2019). Today, wind energy can be modular for installations of any size (Sathyajith, 2006; Barthelmie and Pryer, 2014; Wald, 2014).

\subsection{Sustainability and Wind Energy}

Sustainability concerns have given the renewables a new impetus with internationally funded research exploring the potential role of wind energy deployment in climate change mitigation efforts (IPCC $n$. d.). After the signing of the Kyoto Protocol in 1997, the curbing of emissions has become a matter of international environmental politics (Pinske and Kolk, 2009). Scientists of the Intergovernmental Panel for Climate Change (IPCC) have established that it is still possible to limit GHG emissions to avoid the $2{ }^{\circ} \mathrm{C}$ warming threshold (IPCC, n.d.). To achieve this aim, it was calculated that the carbon-free sources could supply $10-31 \%$ of electricity worldwide by 2050 (Barthelmie and Pryer, 2014).

The quantity of energy generated by the wind is potentially limitless, and aside from harnessing, storage and transfer technology, cost-free (Lucas 2006; Cleveland and Morris 2013). Together with solar power, wind power represents one of the most clean and sustainable sources of renewable energy (Climate Economy report, 2014; UCSUSA). Considering all these developments, wind power has gained in popularity (Wind Europe n.d.).

However, the availability and increased affordability of renewable energy barely dent fossil fuel dependence, with Raval and Hook (2019) reporting that oil, gas, and coal are still expected to constitute about $85 \%$ of power by 2040. REN21 states that in total energy use renewables are over $18 \%$ now, but you only quote electricity. Also, projections for a realistic meeting of Paris agreement targets are not optimistic (Leahy, 2019). For the full development of wind energy, some barriers, challenges, and limitations need to be removed: high generation cost, low on-grid price, and stagnating development of domestic manufacture (Han et al, 2009) as well as economic, social and political factors, outlined below.

\section{Results: Barriers to Wind Energy and Failures to Address Climate Change}

Critical scholars have noted that due to historical significance of fossil fuels in bringing about economic growth, and present fixation of neoliberal economics and politics on growth as a common-sense "good" (Washington and Kopnina, 2018), it has often been the governments, and not so much local protestors, that have prevented meaningful sustainable policies (Kopnina and Blewitt, 2018;). Part of this resistance to the sustainable transformation of energy can be explained by the entrenched power of the "carbon democracy" (Mitchell, 2009), or plutocracy based on oil oligarchy (Rozzi, 2015). However, it is not just the governments influenced by industrial and particularly fossil-fuel lobbies that impede the development of clean power.

\subsection{NIMBY Protests}

In a novel by Miguel de Cervantes written in 1605, Don Quixote is fighting the windmills as if they are ferocious giants. In his delusion, he believes that after defeating them he will be able to enjoy fame and glory as a knight. As of the year 2019, the fight with the windmills, or their more modern incarnation, wind turbines, continues. In "Don Quixote on the Katwijk Boulevard" Marijke Visser (2016) describes local resistance in the coastal town in The Netherlands to the plans to build an offshore wind park. The local community stakeholders, entrepreneurs, fishermen, and politicians protested against these plans, complaining about the lack of transparency regarding the 
costs and benefits of the project. This anthropological research also revealed various myths and (mis)conceptions about the reasons for having the wind turbines in the first place (Visser, 2016).

This local Dutch protest is reflected in many locations across the globe, preventing the meeting of the targets for renewable energy to address climate change. Known as NIMBY's ("not in my backyard") protests reveal the 'social gap' between scientific evidence, public opinion, and the local politics of wind energy (Visser, 2016). Social understanding and resistance to wind power installations has multiple causes, such as democratic deficit and qualified support (Bel et al, 2013), the inter-relationship between communities and the land related to place identity, perceived loss of security, a sense of marginalization (Pasqualetti, 2011), and in the case of those living in proximity to windmills, the noise, earth vibrations, obstructed views, and changing landscapes (Smith and Klick, 2007), or dislike of their visual impact (Eagle et al, 2018).

Visser (2016) notes that in Katwijk various forms of narratives and myths arose. As in more instances in the posttruth, fact-free world, stories about the evils of wind power are spread and perceived by stakeholders as 'the truth', supported by lay citizens' "investigations and counter investigations" (perceiving offshore wind power as oldfashioned, non-profitable, and unsustainable) to falsify the claims of opponents (Visser, 2016). One reason for the opposition to wind power is its large scale, perceived as overwhelming (Firestone and Kampton, 2007). Often NIMBY protests are successfully used by those with interest to discredit wind power and to demonstrate that wind farms are unsafe, unhealthy, or even undemocratic as they ignore citizens' objections (Bel et al, 2013; Feurtey et al, 2016; Visser, 2016; Eagle et al, 2018).

A more general issue might be not just that democracy is subordinated to populist, oligarchic, or plutocratic influences, but the very nature of democracy itself. As Novack (2019) has noted, the "problem is NOT that the system of democracy is imperfect. "Perfect" democracy might not lead to the solution of our situation either. The real point is that democracy, even when working perfectly, does not guarantee good, wise, or just decisions. All properly working democracy can do is deliver the decisions that the people want, for good or for ill'. For democracy to deliver decisions dealing with the ecological crisis the people have to want that more than they want other things. To make matters worse, this is a long-term problem. Novack has also stressed that he is not advocating for some system other than democracy as the alternatives are not better and most of them worse. Simply, however, as Lidskog and Elander (2010) have noted, there is nothing inherent about democracy that would guarantee the wisest, altruistic, or scientifically sound decisions regarding climate change. This is due to a myriad of psychological and political conflicting interests, self-interests, desire to fit socially and culturally within established consumerist norms, and the "brainwash" by the neoliberal media supported by entrenched power lobbies (Isenhour, 2010).

\subsection{Environmental and Conservation Concerns}

The opposition of some environmentalists concerned about wind turbines' damage to terrestrial nature, marine life/environmental impacts study of respondents opposing wind farms was recorded in Cape Cod, USA (Firestone and Kempton, 2007). Concerns over the negative ecological impacts of off-shore wind farms include habitat loss, collision risks, barrier effect, noise, vibrations and electromagnetic fields (Inger et al, 2009; Vaissière et al, 2014; Rodríguez-Rodríguez, 2016). In Europe, wind power is demonstrated to affect birds (particularly raptors, migrating birds and waterfowl) and bats, as well as marine mammals including small cetaceans, particularly harbor porpoises and harbor seals (Rodríguez-Rodríguez, 2016). Avian mortality is one of the most-documented concerns, with many collision victims being raptors and griffon vultures (De Lucas et al, 2008).

\subsection{The Government's and the Media's Role in Opposition}

Strategic use of public concerns with windmills in the media tends to underplay the long-term negative effects of fossil fuel energy (Washington, 2015). This is a dangerous trend - not just regarding the use of wind power in particular, but as a general tendency in which the severity of the environmental predicament is denied (Dunlap and McCright, 2011).

The present subsidy regimes that support fossil fuels lower the chances of meeting the post-Kyoto Protocol agreements (Leahy, 2019). Basically, the governments might be "in the pocket" of established power lobbies, deserving the name of "oil democracy" (Mitchell, 2009; Rozzi, 2015), with "fake news" and fabricated facts exaggerating the negative role of wind farms "research" sponsored by vested fossil interest groups (Rattiner, 2018).

Simultaneously, climate denial has been fueled by industrial lobbies' funding of certain research institutes and media keen to maintain the status quo (McRight and Dunlap, 2011). It is the deniers who claim they are skeptics but true skeptics seek the truth, they do not run away from a truth they deny (Washington and Cook 2011). Recently, opposition to government interventions to regulate energy due to concerns about social and economic fairness, 
especially in recent years as manifested by the "yellow vests" ('gilets jaunes') movement, that among other things, demands low energy prices and resists a carbon price (Al Jazeera, 2019).

\subsection{Other "Renewable" Alternatives}

Another reason for the failure of climate change mitigation policy is that the alternatives to fossil fuel power, often misleadingly classified as "renewable" or "clean" (or at least "cleaner") energy have not been much better than fossil fuels, including initiatives such as substituting wood for coal (Reijn, 2019a, b). While the use of wood pellets in Europe has been branded as "renewable", the use of bioenergy derived from palm, soy, or other types of wood for energy has been said to deserve a label of 'environmental lunacy in Europe' (The Economist, 2013). The EU's Renewable Energy Directive continues to insist that energy derived from biomass is carbon-neutral, based on the assumption that trees regrow after being cut (Garson, 2019). The bulk of wooden pellets consumed in the European Union come from Eastern Europe (Reijn, 2019b) and the United States and Canada, as well as from developing countries (Kopnina, 2016; Garson, 2019). Despite presently plentiful supply from economically less developed to wealthier countries, the growth of "green" fuel plantations requires clearing originally biodiverse habitats, eliminating biodiversity but also their ability to serve as carbon sinks, as newly planted trees take a long time to grow before they are cut again (Eggers 2009; Kopnina, 2017; Garson, 2019). Also, plantations for biofuels were noted to disrupt food security, as well as related to fuel rebound effects, when people use more fuel or energy assuming it is 'sustainable' (Ghosh and Westhoff, 2019).

\subsection{The Cost of Wind Power}

Another principal argument against the renewables is that their costs of building and technology enabling effective distribution of wind energy still exceed those of conventional energy sources such as coal, oil, natural gas, and nuclear energy (Nemetz, 2013). Yet, REN21 and International Renewable Energy Agency (IRENA) clearly show that renewables such as wind are cheaper than new coal-fired electricity IRENA (2018) notes:

Electricity from renewables will soon be consistently cheaper than from fossil fuels. By 2020, all the power generation technologies that are now in commercial use will fall within the fossil fuel-fired cost range, with most at the lower end or even undercutting fossil fuels.

Jacobson et al (2018) emphasize that renewables are now of similar price to the fossil fuel systems. However, they point out that when one considers the full costs of energy + health + climate, renewables are only a quarter the cost of the current fossil fuel systems. They conclude (p. 247) that it is fully possible to reach: 'a fully integrated all-sector $100 \%$ clean, renewable, efficient, and reliable energy infrastructure by 2050 , if not sooner'. Offshore turbines have higher costs because of the need of higher maintenance due to increased force of marine wind storms, flooding, and salt water-caused corrosion, that can damage wind farm installations (Greaves and Iglesias, 2018).

\section{Discussion: Ways Forward in Addressing Resistance}

\subsection{Addressing the NIMBY's}

Returning to Don Quixote in Katwijk, Visser (2016) writes that ways forward include a stakeholder involvement to decrease resistance. Both groups of opponents and proponents of wind power share certain similarities. While proponents of wind energy in Katwijk, like in many other localities in the world, demonstrate a clear awareness of the necessity of renewable energy, they also share the feelings of 'being unheard' by the officials (Visser, 2016). However, while proponents of wind power in Katwijk express distrust of their local officials, the opponents distrust the government officials. Stakeholder engagement can be increased by involving local people into decision-making processes, but simultaneously aiming to provide comprehensive, non-technical evidence for why wind power is not only sustainable but can be beneficial for this region and different groups of stakeholders (Visser, 2016).

What is also significant in this Dutch case, is that once the stakeholders are heard, some reasonable ideas emerge. Visser has discovered that a number of her respondents, even in the militant opposition to wind power "camp", point to new technologies to tackle the climate problem, like tidal wave power, 'blue energy' (energy generated from the interaction between fresh and saltwater) and solar power. Visser (2016:2) writes: "Acknowledgement of the regional specific circumstances and sensitivity for the socio-historical roots can strengthen the feelings of being heard". She also notes the need for transparent communication to enhance the trust between members of the local communities and project managers:

"Explicit information about the pros and cons, and the facts and figures will increase the inhabitants' knowledge and awareness. To achieve an open and transparent stakeholder involved approach, consensus between national and local government about the facts and figures of the policy is required" (Visser, 2016:2). 
This approach to working with community-based protests can address some of the issues associated with "corrupt" democracies (Mitchell, 2009; Rozzi, 2015) or an even trickier issue of the relationship between democracy and climate change (Lidskog and Elander, 2010).

To address the interference of wind turbines with the landscape or noise pollution, and a sense of marginalization, considering the relationship between land and life by project planners, and discussions with local communities, can help smooth some potential conflicts (Pasqualetti, 2011; Visser, 2016). More pragmatically, offshore farms further from inhabited areas have been built, with project managers hoping to compensate for higher costs of offshore turbines by avoiding resistance.

\subsection{Addressing Environmental and Conservation Concerns}

In the case of marine life, Firestone and Kempton (2007) showed that the opinion-based beliefs appear to be factually incorrect. The negative effects of climate change and overfishing on the marine environment are much more significant than the impact of wind turbines (WWF, n.d). The negative environmental effects of wind farms in (among other things) disrupting bird migrations have been exaggerated by the media (Traube, 2004), while the positive role has been underplayed (Inger et al, 2009). The same media is less inclined to discuss the long-term effects of climate change disrupting not only birds, but endangering habitats and food supply that the birds and other species are dependent on, with profound changes leading to irrevocable changes or "tipping points" leading to extinction (Pimm, 2009; WWF, n.d.). Few griffon vultures killed by wind turbines (da Lucas et al, 2009), but most are endangered due to other factors, such as climate change, hunting, the use of agricultural pesticides, electrocutions, and lack of available food (Becker et al, 2010). The direct positives include the capacity of offshore wind turbine installations to act as "both artificial reefs and fish aggregation devices", facilitating "restoration of damaged ecosystems", and "enhancing both biodiversity and fisheries" (Inger et al, 2009:1145).

It is, however, very important not to under-estimate some negative impacts of offshore wind farms, and the ocean environment needs monitoring and safeguarding while these technologies are developed (Pelc and Fujita, 2002; Inger et al, 2009; Neri et al, 2019). Environmental Impact Assessment in relation to wind farms and biodiversity needs to consider mitigation hierarchy, including measures that would avoid, reduce, and if possible offset significant adverse effects on ecosystems (Vaissière, et al 2014). Technological innovation, such as like floating turbines may help reduce current environmental impacts of marine windfarms (Rodríguez-Rodríguez et al, 2016). Overall, the effect of wind energy on biodiversity needs to be carefully weighed with alternatives such as fossil fuels or biofuels, that seem to have a much larger impact, long-term, directly or indirectly, on the flourishing of habitats.

\subsection{Addressing the Government and Corporate Resistance}

Critical scholars have maintained that many sustainability efforts have only worked to 'sustain the unsustainable' (Blüdhorn, 2007), for example promoting electric cars that still use electricity derived from fossil-fuels (Isenhour, 2010), with corporate and political greenwashing and window-dressing through 'sustainababble' (Engelman, 2013). Neoliberal governments have readily delegated responsibility for the choice of energy to citizens and refusing to make unpopular decisions that would limit economic growth (Isenhour, 2010). Despite the perceived risks of climate change, it seems that the public and politicians remain in the state of impassivity or even denial (Dunlap and McCright, 2011).

Considering this, the opposition to wind power remains problematic, directly or indirectly fueled (pun intended) by the established power lobbies or prey to unrealistic expectations (Nemetz, 2013). For example, the Institute for Energy Research, which has been producing anti-wind energy research and media coverage, has board members in the oil and gas industry (Rattiner, 2018). The same lobbies, supported by media and some members of the public, argue that the fossil fuel economy secures jobs and leads to economic prosperity (Pinske and Kolk, 2009; Kopnina, 2016). However, since the effects of climate change are becoming to manifest themselves in the form of droughts floods and fires that hurt the economy and worsen refugee crises, this creates a new economic incentive for governments and corporate leaders to support renewable energy.

\subsection{Addressing Other "Renewable" Alternatives}

Unlike wind, trees or other sources of "green" matter have multiple ecological functions, outlined in the book Cradle to Cradle by Braungart and McDonough (2010). The authors explain the principle of eco-effectiveness (rather than eco-efficiency) by the central metaphor of a cherry tree, which blossoms every year. While most of these blossoms do not succeed in making more cherry trees through pollen or seeds, their reproduction is helped by other species that eat the berries and carry the seeds. The "waste" (this term is used herein a similar way that the wooden pallet makers argue that their product is made of "waste" material of timber production) serves an even 
more important purpose (McDonough and Braungart, 2010). This purpose is to replenish the soil that supports not only new trees but also billions of other smaller species, including grasses, fungi, and other microorganisms enabled to thrive and reproduce by this "waste". This nurturing process becomes impossible when vital biomass goes up in smoke for a short spurt of energy (Braungart, 2013).

These types of "alternatives" that pretend to be "circular" still require material inputs (Rammelt and Crisp, 2014). In comparison to other sources of renewable energy, including liquid and solid biomass and waste, wind power does not use material resources that can be exhausted, as in the case of burning waste, which actually contains valuable mixed materials (Braungart, 2013); or include potentially hazardous by-products such as nuclear waste (Sathyajith, 2006; Barthelmie and Pryer, 2014; Renewable Energy World, 2015). Clear communication of the Cradle to Cradle and circular economy framework can help to address the issue of best intentions and wrong choices in terms of "renewable" alternatives (Kopnina, 2018; Kopnina and Blewitt, 2018). Since renewable energy does not involve depletion of resources, aside from its capture and storage devices, and it should not be compromised by allowing fossil fuels to be part of the 'mix' and therefore ensuring that their use continues. indeed!

\subsection{Addressing the Costs}

The new technological improvements have helped to avoid jeopardizing a utility's ability to meet constantly fluctuating customer demand (Fang et al, 2011). The cost depends on the intention of the conventional power companies to buy excess power from many small, disseminated wind power sources at a reasonable price. This has been the subject of new rules and regulations, such as "feed-in tariffs", also known as FITs (Climate Economy report, 2014). FITs pay consumers, including households, landlords, businesses and organizations such as schools and care homes, for creating their own "green electricity" (http://www.fitariffs.co.uk/FITs/).

Another side for the solution is financial and long-term prosperity gains that both industrial and political stakeholders find most appealing, which is due to technological developments that make wind power more successfully stored and transferred (Fang et al, 2011). Technologies for generating and storing wind power have been rapidly improving. The significant enlargement of the grid system, linking a large number of geographically dispersed wind parks has helped to transfer power at great distances. This type of highly interconnected grid system could emulate the requirements of current energy supply systems (Fang et al, 2011). Increased awareness of economic benefits and actual job creation brought by wind farms is playing a positive role as well (Loomis et al, 2016).

What is helpful for addressing the costs is subsidies regimes established by governments, which can financially reward the producers and consumers directly, but also, significantly, indirectly through various "hidden" supports, such as rebates, tax exemptions, trade restrictions, limits to market access, and price controls (Pinske and Kolk, 2009; Ellis, 2010; Aldy, 2015).

While the wind power has not always been price-competitive, many newer technologies for harvesting, storing, and transferring wind energy have enabled greater market competitiveness (Climate Economy report, 2014; Watson et al, 2019). With the benefit of economies of scale, wind power has been able to realize substantial decreases in per-unit cost of electricity and provide hope for an environmentally benign generation of global energy (Brown et al 2014; IEA, 2019).

To be fair, we need to note that applying these technologies on the global scale to satisfy billions of people increasingly striving towards a high standard of living, requires a different type of commitment, adjustment, and indeed, perhaps short-term sacrifice than the current political and economic regimes have allowed for. Subsidies, "feed-in tariffs", as well as adjustments on the part of those that live next to the wind farms, and last but not least, cessation of fossil fuel industries' financial backing of anti-renewable energy policies, phasing out of fossil fuel subsidies, and enhanced access to the public stock markets (Tian, 2018) are all needed.

\subsection{Discussing the Role of Democracy}

While for years governments have been instrumental in subsidizing and otherwise supporting fossil-fueled industries, the relatively recent interest of (some) governments in the shift towards renewable energy is relatively new (Pinske and Kolk, 2009). Considering that the dominant language of communication through the media has been (and in many cases continues to be) economy-centered (e.g. Washington, 2015), it is not surprising that sudden appeals to consumer responsibility, and possible sacrifices to living standards, presently meet both corporate and social (NIMBY) resistance. Since part of NIMBY protests are the distrust of government (e.g. Visser, 2016), and many governments' twists and turns in signing and complying to (or not) Kyoto agreement, or later the Paris agreement (Luttikhuis, 2019), within the relatively short periods between democratic elections, this distrust 
is understandable. Scientific expertise backed up by goodwill and a clear communication strategy from policymakers towards the communities is necessary.

There are many groups within every society that actively support climate change efforts, and in fact climate protests have become common-place, or promote environmentally friendly behaviors such as veganism, avoid flying or driving, etc. However, other groups worry about losing their consumer privileges. Relying on the "wisdom of the people" in taking environmentally informed decisions should not be over-estimated (Lidskog and Elander, 2010). Rees (2008:7) suggests that "intelligence and reason may not be the primary determinants of human behavior at any social scale'. Far from being "rational consumers" and wise citizens, in the time of great decisions regarding climate change, our "reptilian brain stem" may override the rational cortex, and we might stick to safe paths (Rees, 2008). These safe paths might be supported by convenient but mistaken assumptions, such as the "goodness" of economic growth and the primacy of individual choices (Washington and Kopnina, 2018). Wanting to be popular with its electorate and avoid collisions with groups such as "yellow vests" who demand low energy prices (Al Jazeera, 2019), the government also has a stake in avoiding unpopular decisions (Isenhour, 2010), thus creating a kind of Faustian pact between the people and the government. Not sure this is unpacked properly? You mean both deny reality and let themselves be fooled (fueled) by a more convenient lie? I think you can say this?

To escape the impasse, Rees (2008) suggests that despite these instincts, our capacity for 'consciousness, reasoned deliberation and willpower' allows us (with effort) to critically examine the "myths we live by" and articulate the necessary conditions for sustainability (Washington, 2015). The impasse between the people, the governments that, hopefully, really try to do "what's best for the people", can be perhaps overcome by the realization of common goals - the government wants to be popular, the people that elect it to have their self-interests (and sometimes altruistic interests) in mind. As Inger et al (2009) suggest in the case of environmental concerns (for the marine environment in this case) about the wind technology, understanding of the advantages of this type of power in comparison with other alternatives, is crucially important. Inger et al write that the deployment of marine installations has:

"the potential to cause conflict among interest groups including energy companies, the fishing sector, and environmental groups. Conflicts should be minimized by integrating key stakeholders into the design, siting, construction and operational phases of the installations, and by providing clear evidence of their potential environmental benefits" (Inger et al, 2009:1145).

Thus, a common language that can reach all stakeholders, explicate standpoints and expectations, and hopefully lead to the articulations of rational (e.g. on the basis of price, and, as cliché as it sounds, an understanding of the necessity of energy transition towards a better future for one's own children) as well as altruistic (perhaps trading in some of the high-consumption lifestyles for the sake of future generations and the environment itself) motivations is necessary to achieve energy transformation.

\section{Conclusion and Policy Implications}

The fact that wind energy harvesting technologies have existed for centuries testifies to the human capacity to invent and maintain sustainable energy systems. Yet social and political barriers to the widespread and acceptance of renewable energy in general and wind power in particular identified in this article still need to be overcome. I have inquired why, despite obvious risks and threats associated with the use of fossil fuels, renewable energy such as wind power has not (yet) resulted in a radical shift away from fossil fuels to renewable energy overstated, it is happening. As discussed above, presently, the 'energy mix' is still dominated by fossil fuels, without a radical transition from the types of technologies and lifestyles that threaten our planet's viability again overstated. Strict adherence to true renewables such as wind and solar power; rejecting "partial" renewables that involve depleting biomass, such as most of the biofuels, promise long-term positive effects in the energy transition.

This article has also discussed concerns with transmission, distribution, and acceptance of wind energy. Resistance to wind energy is fuelled by the entrenched power hierarchies, as industrial power lobbies often play a significant role in controlling and dominating the energy market, as well as in "not in my backyard" (NIMBY) protest movements. Support or resistance to wind power varies per stakeholder and within the groups of stakeholders. In some cases, it is the "top-down" regulation forces national governments to accept certain measures. In the case Katwijk protests, discussed here, the Dutch government's sudden support of renewables is due to the obligation to meet the European Union's sustainable energy targets. The mixed motivation for some to oppose, and for others to support wind farms, hinges on personal convictions, scientific (mis)understanding, (mis)trust of government, and many other factors. To gain public support for wind farms, despite their past policies supporting fossil fuels, the government's present motivation needs to be clearly articulated and translated into "local language". This can involve information campaigns, participation of local stakeholders, and compensation of those that might be (or 
feel) disadvantaged. Above all, the articulation of both rational (e.g. addressing climate change) as well as socially and ecologically altruistic (caring about future generations and the environment) motivations and sharing them with all stakeholders is necessary.

To sum up, research into renewable energy and the barriers to its acceptance briefly reviewed in this article indicates that wind energy is gaining more wind in its sails, and may yet become, together with solar energy, one of the two truly renewable and environmentally benign sources of global energy supply that can be a major part of reducing climate change.

\section{References}

Akorede, M. et al. (2010). Distributed energy resources and benefits to the environment. Renewable and sustainable energy reviews, 14(2), 724-734.

Al Jazeera (2019). Yellow fever: The 'gilets jaunes' and the mainstream media. Retrieved November 2019, from https://www.aljazeera.com/programmes/listeningpost/2019/04/yellow-fever-gilets-jaunes-mainstreammedia-190427122818033.html

Aldy, J. E. (2015). Policy surveillance in the G-20 fossil fuel subsidies agreement: lessons for climate policy. Climatic, 1-14.

Baker, T. (1985). A field guide to American windmills. University of Oklahoma Press.

Barthelmie, R. J., \& Pryer, S. C. (2014). Potential Contribution of wind energy to climate change mitigation. Nature Climate Change, 8, 684-688.

Becker, N. et al (2010). Cost benefit analysis of conservation efforts to preserve an endangered species: The Griffon Vulture (Gyps fulvus) in Israel. Journal of bioeconomics, 12(1), 55-70.

Bell, D. et al (2013). Re-visiting the 'social gap': public opinion and relations of power in the local politics of wind energy. Environmental Politics, 22(1), 115-135.

Blüdhorn, I. (2007). Sustaining the unsustainable: Symbolic politics and the politics of simulation. Environmental Politics, 16, 251-275.

Boserup, E. (1965). The conditions of agricultural growth: The economics of agrarian change under population pressure. Aldine, Chicago, IL.

Braungart, M. (2019). Waste to energy. 2013. Retrieved November 2019, from http://catalystreview.net/2010/02/cradle-to-cradle-transitioning-from-waste-incineration-to-beneficialmaterials/

Brown, L. R. et al. (2014). Vital Signs 2000-2001: The Environmental Trends that are Shaping Our Future. Routledge, 2014.

Buehler, R. (2018). Can public transportation compete with automated and connected cars? Journal of Public Transportation, 21(1), 2 .

Cleveland, C. J., \& C. G. Morris. (2013). Handbook of Energy: Chronologies, Top Ten Lists, and Word Clouds. 2. Elsevier, 2013.

Climate Economy report. Retrieved November 2019, from http://2014.newclimateeconomy.report/energy/.

Curtin, J., et al (2018). How can financial incentives promote local ownership of onshore wind and solar projects? Case study evidence from Germany, Denmark, the UK, and Ontario. Local Economy, 33(1), 40-62.

De Lucas, M. et al (2008). Collision fatality of raptors in wind farms does not depend on raptor abundance. Journal of applied ecology, 45(6), 1695-1703.

Dunlap, R. E., \& McCright, A. M. (2011). Organized Climate Change Denial. In John S. Dryzek, Richard B. Norgaard, \& David Schlosberg (Eds.), The Oxford Handbook of Climate Change and Society.

Eagle, L. et al (2018). Winds of change: a study of the acceptability of renewable energy in regional Australia. In: Proceedings of the International Social Marketing Conferences. pp. 47-52. From: International Social Marketing Conference: broadening cultural horizons in social marketing, 15-17 July 2018, Singapore, 47-52.

Ehrlich, P. R. (1968). The Population Bomb. New York: Ballantine Books.

Ellis, J. (2010). The Effects of Fossil-Fuel Subsidy Reform: A review of modeling and empirical studies." Available at SSRN 1572397.

Energy Saving Trust, UK. Retrieved November 2019, from 
http://www.energysavingtrust.org.uk/domestic/content/feed-tariff-scheme

Energy. Gov. History of Wind Energy. Retrieved November 2019, from http://energy.gov/eere/wind/history-windenergy

Engelman, R. (2013). Beyond sustainababble. In Starke, L. (Ed.), State of the World 2013: Is Sustainability Still Possible? Washington: Island Press.

EPA. Climate change: GHG emissions. Retrieved November 2019, from http://www3.epa.gov/climatechange/ghgemissions/global.html

Fang, X. et al. (2011). Smart grid-The new and improved power grid: A survey. IEEE communications surveys \& tutorials, 14(4), 944-980.

Feurtey, É. et al. (2016). Institutional factors influencing strategic decision-making in energy policy; a case study of wind energy in France and Quebec (Canada). Renewable and Sustainable Energy Reviews, 59, 1455-1470.

Firestone, J., \& W. Kempton. (2007). Public opinion about large offshore wind power: underlying factors. Energy policy, 35(3), 1584-1598.

Garson, K. (2019). Dangerous delusions: Biomass is not a renewable energy source. Leonardo di Caprio Foundation. Retrieved November 2019, from https://www.leonardodicaprio.org/dangerous-delusionsbiomass-is-not-a-renewable-energy-source/

Ghosh, P. et al. (2019). Biofuels, food security, and sustainability. In Biofuels, Bioenergy and Food Security, pp. 211-229. Academic Press.

Greaves, D., \& G. Iglesias. (2018). Wave and tidal energy. John Wiley \& Sons.

Han, J., et al. (2009). Onshore wind power development in China: Challenges behind a successful story. Energy Policy, 37(8), 2941-2951.

Harvey, C. (2018). CO2 Emissions Reached an All-Time High in 2018. Scientific American.

Al-Hassan, A. Y., \& D., R. Hill. (1986). Islamic Technology: An illustrated history. Cambridge, England: Cambridge University Press.

Higham, J., et al. (2019). Tourist aviation emissions: A problem of collective action. Journal of Travel Research, 58(4), 535-548.

Higham, J., et al. (2014). Climate change, tourist air travel, and radical emissions reduction. Journal of Cleaner Production.

Hills, R. (1996). Power from wind: A history of windmill technology. Cambridge University Press.

Hobbs, F., \& N., Stoops. (2002). Demographic trends in the 20th century, 4. US Census Bureau.

IEA (International Energy Agency) 2013. Renewables: Wind. Retrieved November 2019, from http://www.iea.org/topics/renewables/subtopics/wind/

IEA (International Energy Agency) 2019. Offshore Wind Outlook 2019. Retrieved November 2019, from https://www.iea.org/newsroom/news/2019/october/offshore-wind-to-become-a-1-trillion-industry.html

Illustrated History of Wind Power Development. Retrieved November 2019, from http://telosnet.com/wind/20th.html

Inger, R., et al. (2009). Marine renewable energy: Potential benefits to biodiversity? An urgent call for research. Journal of Applied Ecology, 46(6), 1145-1153.

IPCC n.d. (2019). Retrieved November 2019, from https://www.ipcc.ch/report

Isenhour, C. (2010). On conflicted Swedish consumers, the effort to stop shopping and neoliberal environmental governance. Journal of Consumer Behaviour, 9(6), 454-469.

Kindall, H. W., \& Pimentel, D. (1994). Constraints on the Expansion of the Global Food Supply. Ambio, 23(3), Royal Swedish Academy of Sciences.

Kopnina, H. (2011). Kids and cars: Environmental attitudes in children. Transport Policy, 18(4), 573-578.

Kopnina, H. (2016). Energy Policy in the European Union: Renewable Energy and the Risks of Subversion." In Governance and Security Issues of the European Union, pp. 167-184. TMC Asser Press, The Hague.

Kopnina, H. (2017). Commodification of natural resources and forest ecosystem services: examining implications for forest protection. Environmental Conservation, 44(1), 24-33. 
Kopnina, H. (2018). Circular economy and Cradle to Cradle in educational practice. Journal of Integrative Environmental Sciences, 15(1), 119-134.

Kopnina, H., \& Blewitt, J. (2018). Sustainable Business: Key issues. Second Edition. Routledge, New York.

Leahy, S. (2019). Most countries aren't hitting 2030 climate goals, and everyone will pay the price. National Geographic. Retrieved November 2019, from https://www.nationalgeographic.com/science/2019/11/nationsmiss-paris-targets-climate-driven-weather-events-cost-billions/

Lidskog, R., \& I., Elander. (2010). Addressing climate change democratically. Multi-level governance, transnational networks, and governmental structures. Sustainable Development, 18(1), 32-41.

Loomis, D. G. et al. (2016). Economic impact of wind energy development in Illinois. Journal of Business Valuation and Economic Loss Analysis, 11(1), 3-23.

Lucas, A. (2006). Wind, Water, Work: Ancient and Medieval Milling Technology. Brill Publishers. p. 105.

Luttikhuis, P. (2019). Parijs' hapert, met of zonder VS [Paris is faltering, with or without the US] NRC. Retrieved November 2019, from https://www.nrc.nl/nieuws/2019/11/03/parijs-hapert-met-of-zonder-vs-a3979010

McCright, A., M., \& R. E. Dunlap. (2011). The politicization of climate change and polarization in the American public's views of global warming, 2001-2010. The Sociological Quarterly, 52(2), 155-194.

McDonough, W., \& M., Braungart. (2010). Cradle to cradle: Remaking the way we make things. North Point Press.

Mitchell, T. (2009). Carbon democracy. Economy and Society, 38(3), 399-432.

Nehring, R. (2009). Traversing the mountaintop: world fossil fuel production to 2050. Philosophical Transactions of the Royal Society B: Biological Sciences, 364(1532), 3067-3079.

Nemetz, P. (2013). Business and Sustainability Challenge: An Integrated Perspective. New York: Routledge.

Neri, M., et al. (2019). Green versus green? Adverting potential conflicts between wind power generation and biodiversity conservation in Brazil. Perspectives in Ecology and Conservation, 17(3), 131-135.

Neslen, A. (2019). Wind power is the cheapest energy, EU analysis finds. The Guardian. Retrieved November 2019, from http://www.theguardian.com/environment/2014/oct/13/wind-power-is-cheapest-energyunpublished-eu-analysis-finds

Novack, M. D. (2019). Discussion thread "Book "Biodiversity and Democracy. E-mail communication on Ecocentric Alliance listserv. Retrieved November 7, 2019, from https://groups.google.com/d/msgid/ecocentric-alliance/7158bb60-6bf7-85bf-2aff 6ef $48 \mathrm{~b} 5 \mathrm{f} 9556 \% 40$ comcast.net

Oestergaard, M. (2015). Strategic climate change communication-The European Wind Energy Association in a discourse strategy trap.

Pasqualetti, M. J. (2011). Opposing wind energy landscapes: a search for a common cause. Annals of the Association of American Geographers, 101(4), 907-917.

Pelc, R., \& R. M. Fujita (2002). Renewable energy from the ocean. Marine Policy, 26(6), 471-479.

Perera, F. (2018). Pollution from fossil-fuel combustion is the leading environmental threat to global pediatric health and equity: Solutions exist. International journal of environmental research and public health, 15(1), 16.

Pimm, S. L. (2009). Climate disruption and biodiversity. Current Biology, 19(14), R595-R601.

Pinske, J., \& A., Kolk. (2009). International business and global climate change. Routledge, 2009.

Rammelt, C., \& Crisp, P. (2014). A systems and thermodynamics perspective on technology in the circular economy. Real-world economics review, 68, 25-40.

Rattiner, D. Wind Farm Fake News. (2018). Retrieved November 2019, from https://www.danspapers.com/2018/06/wind-farm-opposition-truth-lies/

Raval, A., \& Hook, L. (2019). Renewable Energy Push Barely Dents Fossil-Fuel Dependence. Retrieved November 2019, from https://www.ft.com/content/4c77a13a-b50b-11e9-8cb2-799a3a8cf37b

Rees, W. (2008). Toward Sustainability with Justice: Are Human Nature and history on Side? In C. Soskolne (Ed.), Sustaining Life on Earth: Environmental and Human Health through Global Governance. New York: Lexington Books. (2008) 
Reijn, G. (2019). Elektriciteitscentrale verruilt steenkool voor hout, maar is dat wel zo duurzaam? [The power plant trades coal for wood, but is that sustainable?] Retrieved November 2019, from https://www.volkskrant.nl/economie/elektriciteitscentrale-verruilt-steenkool-voor-hout-maar-is-dat-wel-zoduurzaam b2871ef7/

Reijn, G. (2019). Estland draait op hout, maar voor hoelang nog? [Estonia runs on wood, but for how long? Volkskrant, October 29. (2019b)

Renewable Energy World. (2019). Wind Energy. Retrieved November 2019, from $\mathrm{http}: / /$ www.renewableenergyworld.com/rea/tech/wind-power

Ritter, M., \& L., Deckert. (2017). Site assessment, turbine selection, and local feed-in tariffs through the wind energy index. Applied energy, 185(2017), 1087-1099.

Rozzi, R. (2015). Implications of the biocultural ethic for earth stewardship. In Earth Stewardship, pp. 113-136. Springer, Cham.

Sathyajith, M. (2006). Wind energy: fundamentals, resource analysis, and economics. Springer.

Setboonsarng, S. (2015). Organic Agriculture, Poverty Reduction, Climate Change, and the Millennium Development Goals. Organic Agriculture, 3.

Smil, V. (1994). The Energy in World History. Boulder, CO: Westview.

Smith, E., \& H. Klick. (2007). Explaining NIMBY opposition to wind power. In Annual Meeting of the American Political Science Association, pp. 1-19.

Sorensen, B. (1995). History of, and Recent Progress in, Wind-Energy Utilization. Annual Review of Energy and the Environment, 20(1), 387-424.

Teleke, S., et al. (2010). Optimal control of battery energy storage for wind farm dispatching." Energy Conversion, IEEE Transactions on, 25(3), 787-794.

Temin, P. (1966). Steam and waterpower in the early nineteenth century. The Journal of Economic History, 26(2), 187-205.

The Economist. (2013). Wood: The fuel of the future. Environmental lunacy in Europe. Retrieved November 2019, from http://www.economist.com/news/business/21575771-environmental-lunacy-europe-fuel-future

Tian, H. (2018). Role of Capital Market to Accelerate the Transition to Low-Carbon Energy System. Financing for Low-carbon Energy Transition, 211-238. Springer, Singapore.

Traube, K. (2004). Renewable energy and nature conservation. Energy \& Environment, 15(4), 625-631.

UCSUSA [The Union of Concerned Scientists] How Wind Energy Works. Retrieved November 2019, from https://www.ucsusa.org/resources/how-wind-energy-works

UN (United Nations) (1987). Our Common Future, Chapter 4: Population and Human Resources. Retrieved November 2019, from http://www.un-documents.net/ocf-04.htm

Vaissière, A. C., et al. (2014). Biodiversity offsets for offshore wind farm projects: The current situation in Europe. Marine Policy, 48, 172-183.

Visser, M. (2016). Don Quichot op de Katwijkse Boulevard. [Don Quichot on the Katwijk Boulevard]. Master's thesis. Institute of Cultural Anthropology and Sociology, Leiden University, 2016.

Wald, M. (2019). Texas is wired for wind power, and more farms plugin. The New York Times July 23. Retrieved November 2019, from https://www.nytimes.com/2014/07/24/business/energy-environment/texas-is-wiredfor-wind-power-and-more-farms-plug-in.html

Washington, H. (2015). Demystifying Sustainability: Towards Real Solutions. London, Routledge.

Washington, H., \& H. Kopnina. (2018). The insanity of endless growth. The Ecological Citizen, 2, 57-63.

Watson, S. et al. (2019). Future emerging technologies in the wind power sector: A European perspective. Renewable and Sustainable Energy Reviews, 113, 109270.

White, L. Jr. (1962). Medieval technology and social change (p86 \& pp. 161-162), Oxford.

Wind Energy. The Facts. Retrieved November 2019, from http://www.wind-energy-the-facts.org/

Wind Europe. Retrieved November 2019, from https://windeurope.org

WWF. n.d. (2019). Climate change. Retrieved

November 2019, from 
http://wwf.panda.org/our_work/oceans/problems/climate_change

Zavestoski, S. (2011). Environmental Health Organizing in a Globalizing World: The Emergence of a Global AntiToxics Movement and its Political, Legal and Economic Challenges. In Kopnina, H., \& Keune, H. (Eds.), Health and Environment: Social Science perspectives. Nova Science Publishers, Inc. New York. 2010.

Zhao, H., et al. (2015). Review of energy storage system for wind power integration support. Applied Energy, $137(2015), 545-553$.

\section{Copyrights}

Copyright for this article is retained by the author(s), with first publication rights granted to the journal. This is an open-access article distributed under the terms and conditions of the Creative Commons Attribution license (http://creativecommons.org/licenses/by/4.0/). 